\title{
Comparative effect of vitamin E compounds on HSP70 expression in response to acute redox imbalance in Chang liver cells
}

\section{Somayeh Alsadat Hosseini Khorami}

University of Manitoba Faculty of Agricultural and Food Sciences

Mohd Sokhini Abd Mutalib

Universiti Putra Malaysia

Huzwah Khaza'ai ( $\sim$ huzwah@upm.edu.my )

Universiti Putra Malaysia

\section{Research}

Keywords: HSP70, antioxidant, vitamin E, tocopherol, tocotrienol

Posted Date: April 21st, 2020

DOI: https://doi.org/10.21203/rs.3.rs-22336/v1

License: (c) (i) This work is licensed under a Creative Commons Attribution 4.0 International License.

Read Full License 


\section{Abstract}

Background: HSP70 represents the most highly induced member of the stress protein family which is constitutively expressed in normal cell conditions as chaperon and rapidly upregulated in response to stress conditions. Vitamin E compounds are considered to be the most potent oxidation chain breaking compounds. Although a-tocopherol, has been long considered as the most potent antioxidant among the vitamin $\mathrm{E}$ isomers, many studies have recently suggested a higher antioxidant potency of tocotrienols compared to tocopherols. Present study was carried out to investigate the effects of tocotrienol supplementation compared to a-tocopherol on HSP70 expression.

Methods: To assess whether the increase in HSP70 secondary to the stress caused by the oxidant could decrease in the presence of vitamin E; two groups of cells were incubated for 4 hours with a-tocopherol and palm tocotrienol-rich fraction respectively with concentration of 10,20 and $30 \mu \mathrm{g} / \mathrm{ml}$ after the cells were pre-exposed to oxidative stress.

Results: The comparison between the negative control which represents the basal expression of HSP70 and the positive control that represents the expression of HSP70 as a response to the oxidant, has clearly indicated that treatment with $100 \mu \mathrm{M}$ copper sulphates for 24 hours resulted in a significant up-regulation of HSP70 expression. The present study has shown that the overall effect of vitamin E compounds seems to reduce the increase in HSP70 expression. a-tocopherol tended to trigger a more constant rate of response to the dose given but unable to significantly induced the decrease of the HSP70 expression as compared to tocotrienol.

Conclusion: Treatment with vitamin E has conferred significant protection against stress induced cellular damage. Whether the reduction of HSP70 by vitamin E is deleterious or beneficial is still controversial and needs to be considered.

\section{Introduction}

Cells are adapting to changes in environment continually which resulting in regulation of gene expression to readjust to new physiological situations. Some of these changes may cause cellular integrity and prompt the stress response. Expression of heat shock proteins (HSP) is a general response to a variety of chemical, physical and physiological stresses, which can be directed at conserving cell integrity for survival. HSP belong to a family of well-conserved proteins and classified according to molecular weights: Hsp60, 70, 90, 100, and small HSP (1). Some of HSPs participate in several basic processes and present within the cells constitutively, such as stabilization of substrates, protein folding and assembly of macromolecule structures (2). Upon stress conditions, expression of HSP is induced to participate in folding of degraded and denatured polypeptides as a consequence of insult. Furthermore, HSP can stabilize numerous cellular processes affected by stress conditions including transcription, splicing, translation and transport. Also, damaged macromolecules which are under repair and cellular debris which need to be disposed, requiring HSP for their process (3). 
Oxidative stress induces adaption in expression of protective enzyme and heat shock proteins (HSPs) in a variety of tissues. HSP70 represents the most highly induced member of the stress protein family and it is suggested to have significant cytoprotective effects against a variety of stressors. Vitamin $E$ is the major soluble, chain breaking antioxidant in the body, comprises eight structurally related lipid soluble compounds, $\alpha-, \beta$-, $\gamma$ - and $\delta$-tocopherol; and $a-, \beta-, \gamma$ - and $\delta$-tocotrienol. Little is known about the effect of vitamin E compounds on expression of HSP70 in oxidative stressed cells. The aim of this study is to examine the influence of oxidative stress on HSP70 expression and to compare the effects of atocopherol and a-tocotrienol on oxidative-influenced HSP70 in Chang liver cells.

This study is a contribution to the ongoing research on heat shock proteins, particularly HSP70, as the most remarkable member of the stress proteins. HSP70 offers great potential as a therapeutic target in diverse range of human disease pathologies associated with trauma, stress, and the expression of damaged and misfolded proteins. Therefore, better understanding of the conditions which lead to the reduction or increase of HSP70 expression will certainly assist in development of future therapeutic treatments.

Moreover, this study aids the growing concern on understanding the potential properties of tocotrienols compared to tocopherols. The abundance of a-tocopherol in human body and the comparable efficiency of all vitamin $\mathrm{E}$ molecules as antioxidants, led biologists to neglect the non-tocopherol vitamin $\mathrm{E}$ molecules as topics for basic and clinical research. Work on tocotrienols account for only $1 \%$ of the total literature on vitamin E (4). In conclusion, the effect of both TRF and a-tocopherol was examined and contrasted. The understanding of the influence of vitamin E compounds on cell HSP70 expression will provide invaluable tools to unravel further the potential of the cells for protection against stressful conditions.

\section{Methodology}

The cryopreserved human liver cell line CCL-13 (Chang liver, CHL; an immortalized non-tumor cell line derived from normal liver, purchased cryopreserved from the American Type Collection (A.T.C.C.)) were thawed and cultured in DMEM (Dulbecco's modified Eagle's medium) (GIBCO ${ }^{\circledR}$ ), supplemented with 15\% $(\mathrm{v} / \mathrm{v})$ foetal bovine serum and $50 \mathrm{U}$ of penicillin $-50 \mu \mathrm{g} / \mathrm{ml}$ of streptomycin solution (GIBCO®); in T-75 cell culture flask (NUNC ${ }^{\circledR}$ ) and incubated in a humidified atmosphere containing $5 \% \mathrm{CO}_{2}$ at $37^{\circ} \mathrm{C}$. Upon reaching $80-90 \%$ confluence, the cells were subcultured. Haemocytometer counting was performed to estimate the total cell number of cultured cells. Table 1 summarizes these findings.

Treatment of cells: The cells were induced for oxidative stress when they reached $70-80 \%$ confluence, by incubating the cells with $100 \mu \mathrm{M} \mathrm{CuSO}{ }_{4}$ for 24 hours at $37^{\circ} \mathrm{C}$ and $5 \% \mathrm{CO}_{2}$. The medium was then removed and replaced with fresh medium containing either a-tocopherol or a-tocotrienol rich fraction with concentration of $10,20,30 \mu \mathrm{g} / \mathrm{ml}$ for another 4 hours at $37^{\circ} \mathrm{C}$. Cells incubated with $100 \mu \mathrm{M} \mathrm{CuSO}{ }_{4}$ without antioxidants were used as positive control, whereas cells with no oxidant or antioxidant applied were 
used as negative control. Ten T-75 cell culture flasks were used, two for the negative control, two for the positive control, three for natural a-tocopherol treatment, and three for a-tocotrienol fraction treatment.

Total cellular RNA was extracted based on the single-step method of RNA isolation by acid GuanidiniumPhenol-Chloroform extraction as described by Chomczynski \& Sacchi (5). All glassware, plasticware including tubes and micropipette tips were soaked in DEPC treated water and autoclaved to reduce RNase contamination. Concentration of RNA was quantified by using Eppendorf Biophotometer and quality was analysed by gel electrophoresis. As RNase is prevalent in the environment, hence the conversion of RNA to cDNA should be done immediately following the quality control assessment to preserve RNA integrity.

In present study, the optimal concentration of $\mathrm{MgCl}_{2}$ and DNA polymerase for the primer was at $1.5 \mathrm{mM}$ of $\mathrm{MgCl}_{2}$, and 2.5 units of Taq DNA Polymerase respectively (the normal range of Taq DNA Polymerase used was between 1-1.5 units).

RT-PCR was performed to compare the expression of HSP70 mRNA in Chang liver cells in response to the different levels of Palm-Tocotrienol rich fraction and a-tocopherol in presence of exogenous oxidant. Gene-specific primer was designed by First BASE laboratories SDN BHD.

\section{Statistical Analysis}

To assess the significance of differences in expression of HSP70, the unpaired Student's t test was carried out by using the Minitab 18 sofware. Data were expressed as Mean $\pm S E M$. $p<0.05$ were considered significant.

\section{Result}

Chang liver cells were incubated at $37^{\circ} \mathrm{C}$ with $100 \mu \mathrm{M} \mathrm{CuSO}_{4}$ for 24 hours. Then incubated at $37^{\circ} \mathrm{C}$ with palm TRF $(10,20,30 \mu \mathrm{g})$ or a-tocopherol $(10,20,30 \mu \mathrm{g})$. tcRNA was extracted by using the acid Guanidinium-Phenol-Choloroform extraction, and RT-PCR semi quantitative analysis was performed to examine HSP70 expressions. Gene expression was determined by measuring the integrated density values (IDV) of PCR product bands. In absence of the antioxidant, HSP70, expression increased significantly. Palm-TRF significantly reduced HSP70 expression at $20 \mu \mathrm{g}$ and $30 \mu \mathrm{g}$ and was more effective than tocopherol $(10,20,30 \mu \mathrm{g})$. Reduction of HSP70 expression is possibly attributed to the antioxidant properties of vitamin E compounds. Hence, this finding suggests that TRF is a more potent antioxidant than a-tocopherol in vitro. The present study adds to the growing evidence of the greater potency of palm-TRF as radical scavengers compared to tocopherols. Whether oxidative-induced HSP70 down-regulation is beneficial for the cell is still elusive. Further studies on the mechanism by which TRF and tocopherols suppress HSP70 expression and how this influence stressed cells may provide more conclusive explanation.

\section{Discussion}




\section{Expression of Heat Shock Protein 70 in Oxidative Stress}

In present research, the comparison between the negative control which represents the basal expression of HSP70 (31530597.5 $\pm 923268 ; n=4)$, and the positive control that represents the expression of HSP70 as a response to the oxidant (4094970.25 $\pm 10449032 ; n=4)$, has clearly indicated that treatment with 100 $\mu \mathrm{M}$ copper sulphates for 24 hours resulted in a significant up-regulation of HSP70 expression $(p=0.04)$, Figure $1 \&$ Table 2). Overexpression of inducible HSP70 by oxidants has been reported by many other studies $(6,7)$.

The mechanism by which this happens is still elusive, however it is suggested that HSP70 was induced secondary to the adverse effects of oxidative stress on protein conformation $(8,9)$. The oxidative stress here is inducing as a result of increased copper sulphate level which is known to cause oxidative stress due to the overproduction of free radicals particularly hydroxyl radicals. These free radicals attack major cellular molecules and exhaust the antioxidant enzymes inside the cells (10). CuSO ${ }_{4}$ can be reduced from $\mathrm{Cu}^{+2}$ to $\mathrm{Cu}^{+}$by apoplastic ascorbate and/or other electron donors. $\mathrm{Cu}^{+}$formed can participate in a Fenton reaction with apoplastic $\mathrm{H}_{2} \mathrm{O}_{2}$ to form the highly reactive hydroxyl radical ( $\left.{ }^{\circ} \mathrm{OH}\right)(11)$. Consequently, being attack by ROS, proteins may be oxidized, causing carbonylation and aromatic hydroxylation of some amino acids (12). Furthermore, it has been indicated by some studies that oxidation of protein thiols may result in formation of non-native intermolecular disulphide. These alterations in protein structure collectively, can cause proteins to destabilize, denature and unfold so hydrophobic domains are exposed. This would be probably initiating a signal for induction of the heat shock response (13). This has been shown in earlier studies that demonstrated a rapid induction of cytosolic HSP70 expression following the injection of denatured proteins into the cells (14).

Transcription of human HSP70 in response to accumulated denatured and abnormally folded proteins is mediated through the activation of heat shock transcription factor (HSF1). Biochemical and genetic studies have clearly demonstrated critical roles for mammalian heat shock factor 1 (HSF1) in stressinducible HSP gene expression (15). Whether HSF1 directly senses stress or is regulated by an upstream signalling cascade is not yet fully understood. However, what is clear is that in non-stressed conditions when HSP70 levels are in excess- HSF1 is found in the cytoplasm in a non-DNA binding monomeric form, by virtue of its being complexes with HSP70. In the case of oxidative stress, HSP70 recognizes the abnormally folded proteins, possibly through the recognition of the hydrophobic regions, forming longer lived complexes. As a result, HSF1 is liberated from HSP70; phosphorylated and converted to a trimer with the capacity to bind DNA. HSF then translocates from cytoplasm to nucleus where it binds to heat shock elements (HSE) in the promoter region of HSP70 coding genes, and subsequently activates HSPs transcription (16).

Consequently, it can be suggested that the significant induction of heat shock protein 70 mRNA observed in the present study, is possibly attributed to the accumulation of damaged proteins as a result of oxidative stress, and this was mediated, at the transcriptional level, by HSF1. 
The induction of HSP70 following oxidative stress appears to be a part of cellular protective mechanisms to protect against subsequent stress, apparently by preventing or repairing stress-induced protein denaturation and promoting protein folding thus enhancing cells capability to survive $(17,18)$. HSP70 was also shown to effectively inhibit the cellular death processes $(19,20)$. The HSP70 seems to increase resistance against oxidative stress-mediated apoptosis. Reports revealed that HSP70 inhibits apoptosis induced by ethanol, hydrogen peroxide, TNF, UV radiation and several chemotherapeutic agents. All of these treatments have been found to produce ROS within cells during their apoptotic induction (21-23).

The mechanisms by which HSP70 confer protection from ROS and free radicals are not completely understood, but recent studies suggest several possible mechanisms such as : (1) inhibiting protein misfolding and aggregation (24); (2) refolding abnormally folded proteins (25); (3) directing damaged proteins to lysosomes (26), or to peroxisomes to be degraded (27); (4) increasing the expression or the activity of endogenous scavengers of ROS (28); (5) and it also seems to protect DNA, mitochondria from free radicals $(29,30)$.

\section{HSP70 Expression Level in Presence of Vitamin E}

To assess whether the increase in HSP70 secondary to the stress caused by the oxidant could decrease in the presence of vitamin E; two groups of cells were incubated for 4 hours with a-tocopherol and palm tocotrienol-rich fraction respectively with concentration of 10,20 and $30 \mu \mathrm{g} / \mathrm{ml}$ after the cells were preexposed to oxidative stress.

The present study has shown that the overall effect of vitamin E compounds seems to reduce the increase in HSP70 expression (Figure 1). a-Tocopherol tended to trigger a more constant rate of response to the dose given but unable to significantly induced the decrease of the HSP70 expression as compared to TRF (see Figures 1 and Table 3). This observation was supported by some other studies. Topbas and colleagues (31) demonstrated that in liver cells, HSP70 that was induced as a result of vitamin E deficiency, was significantly reduced following re-supplementation with vitamin E. Similarly, vitamin E, particularly a-tocopherol, has been shown to reduce HSP70 levels in human muscles and blood following exercise respectively $(32,33)$, in leukocytes after treadmill running and in human skin fibroblasts after oxidative stress (35).

The mechanism involved in this reduction is not well understood. However, this effect is possibly attributed to the potent antioxidant properties of vitamin $E$ (32). It is likely that the effect of vitamin $E$ on HSP70 was mediated through the scavenging of free radicals and ROS generated by the oxidant and its ability to break radical-propagated chain reactions. As HSF1 is sensitive to redox, it would be imperative to suggest that scavenging of free radicals and the subsequent reduction of the oxidative stress state of cells had possibly inhibited the activation of this factor, and consequently $\operatorname{HSP70}(32,33)$.

Since the 1960s, vitamin E potent antioxidant function had been clearly recognized (36). The strong reducing capacity of vitamin $\mathrm{E}$ is related to its chemical structure. All vitamin $\mathrm{E}$ isomers have active hydroxyl groups attached to benzene ring-based structure and a hydrophobic side chain. It is the hydroxyl 
group that involves in reducing the free radicals since it can easily donate a hydrogen atom, leading to the formation of vitamin E radicals (chromanoxyl) (37). These chromanoxyl radicals are relatively stable and can be reduced back to vitamin $\mathrm{E}$ form by compounds naturally present in biological systems such as ascorbic acid and lipoic acid, in a process termed "recycling" of vitamin E (38). On the other hand, vitamin $E$ side chains are important for the mobility and the incorporation of the vitamin molecules within the membrane phospholipids bilayer $(39,40)$.

As a result of, the present study shows that vitamin E had maintained the reducing environment of the cell, hence prevented the activation of HSF1 and in turn HSP70 by ROS and other free radicals.

\section{Comparative Effect of a-Tocopherol and Palm-Tocotrienol Rich Fraction on HSP70 Expression}

With reference to the positive control (Table 3) HSP70 mRNA was significantly reduced by palm-TRF at $20 \mu \mathrm{g}$ and $30 \mu \mathrm{g}(\mathrm{p}=0.028,0.032$ respectively; $\mathrm{n}=4)$, and this effect was more pronounced at $20 \mu \mathrm{g}$ palmTRF (Table 3). In comparison with the negative control (Table 3), at these concentrations of palm-TRF, HSP70 expression was down-regulated to its basal levels $(p=0.051,0.224$ respectively; $n=4)$.

Palm-TRF also appeared to be more effective in reducing HSP70 expression than a-tocopherol $(10,20$, $30 \mu \mathrm{g})$. Although a-tocopherol $(10,20,30 \mu \mathrm{g})$ had caused a decline in HSP70 expression in a dose dependent manner (Figure 1), this decrease was not statistically significant compared to the positive control $(p=0.814,0.224,0.052$ respectively, see Table 3$)$. However, at 30 $\mu$ g a-tocopherol, HSP70 expression was almost similar to the negative control $(p=0.326)$.

The tocotrienol-rich-fraction (TRF) of palm oil has been anticipated as an efficient alternative for atocopherol due to its potent antioxidant properties in vitro $(41-45)$. Although there was no report on TRF effect on HSP70, the present study findings are in agreement with a number of studies that suggest a higher antioxidant potency of tocotrienols compared to tocopherols in vitro; as HSP70 reduction has been earlier related in this discussion to vitamin $\mathrm{E}$ antioxidant function. It has been reported that a-tocotrienol exhibited significantly greater peroxyl radical scavenging potency than a-tocopherol in phosphatidylcholine liposomes (46). Furthermore, palm-TRF has been also shown to be a more effective inhibitor of LDL oxidation in endothelial cell lipid peroxidation than a-tocopherol in vitro (47). However, in contrast to these findings, a small number of studies suggested that tocopherols and tocotrienols exerted the same reactivity toward radicals and the same antioxidant activities against lipid peroxidation in solution and liposomal membranes. These conflicting findings may be due to the differences in the systems used to conduct these studies (47).

Several reasons have been suggested for the increased antioxidant activity of tocotrienols compared to tocopherols, mostly related to the difference in the hydrophobic side chain saturation level. The unsaturated side chain of tocotrienols has been proposed to allow for more efficient penetration into tissues and increase in the rate of transfer of tocotrienols between liposomal membranes than tocopherols (48). It has been suggested that the higher antioxidant potency of tocotrienols is due to a higher recycling efficiency of the chromanoxyl radicals of the tocotrienols (tocotrienoxyl radical) in 
membranes and lipoproteins, a more uniform distribution of tocotrienols in the cellular membranes, and stronger disordering effect on membranes than a-tocopherol. In addition, studies have indicated that atocotrienols located closer to the membrane surface, which may facilitate recycling (46). These properties are likely result in a more efficient interaction of the chromanol ring of tocotrienols with reactive oxygen species (46).

Despite the fact that the antioxidant efficiency of tocotrienols in vitro is higher than that of tocopherols, these compounds have shown to be less absorbed in vivo than a-tocopherol that is found to be the dominant vitamin $\mathrm{E}$ isomer in human plasma and tissue (49). Possible explanation for the reduced bioavailability includes (1) the presence of a transfer protein in the liver that specifically enriches VLDL with a-tocopherol leading to the secretion of these compounds from the liver in a manner that discriminates between tocopherols and tocotrienols (49), (2) less tissue retention and half-life (3) and the higher rate of tocotrienols metabolism compared to tocopherols (50).

Nevertheless, other studies have indicated that oral intake of tocotrienol makes it bioavailable to all vital organs; even though in significantly lower concentrations than a-tocopherol (51). Nanomolar tocotrienols has been demonstrated to be sufficient to exert antioxidant-independent protective effects in brain (48). The same study has suggested that at micromolar but not nanomolar a-tocotrienol can protect against chemically produced peroxyl radicals $(48,52)$. This effect has been clearly shown in this study.

\section{Conclusion}

\section{Implication of Reduced HSP70 mRNA Levels on Stressed Cells}

Whether the reduction of HSP70 by vitamin E is deleterious or beneficial to the stressed cell is still controversial and needs to be considered. The heat shock proteins vital role in cytoprotection against a variety of stressors that damage the cell and their role in cellular adaption to stress; may suggest that reduced expression by vitamin E may have abolished the adaptive response of stressed cells, or slightly reduced the protective effect of HSP70 (32). However, the findings of this study suggest that the observed effect was apparently secondary to the diminution of cell oxidative stress state due to the scavenging of free radicals and antioxidant properties of vitamin $\mathrm{E}$, since so far there is no recognized mechanism shows the direct interaction between HSF1 or HSP70 and vitamin E. Also, there is a more reduced redox status when vitamin $E$ is supplemented which possibly creates a condition within the cell that does not require additional HSP70 for its cellular protein repair caused by uncontrolled oxidative products.

It is also important to suggest that the presence of antioxidant nutrients in the stressed cell might help to accelerate the process of damaged or unfolded proteins repair accomplished by HSP70 (19).

Consequently, less HSP70 will be needed. This supposition has been supported by some studies which have demonstrated that treatment with vitamin E has conferred significant protection against stressinduced modification of cellular sulfhydryl and carbonyl content. It is also suggested that although HSP70 was reduced, functional levels of cytoprotective HSP70 was maintained (35). Therefore, it is recommended to assess the protective effects of vitamins $E$ in any future study by examining cell 
viability and integrity in conditions when HSP70 is overexpressed and subsequent to the incubation with vitamin $\mathrm{E}$.

\section{Declarations}

Ethics approval and consent to participate

Not applicable

\section{Consent for publication}

Not applicable

\section{Availability of data and materials}

The data that support the findings of this study are available.

\section{Competing interests}

The authors declare that they have no competing interests.

\section{Funding}

This work was financially supported by Universiti Putra Malaysia, Research University Grant Scheme (grant number: 04-02-12-1795RU).

\section{Authors' contributions}

SAHK ${ }^{1}$, MSAM $^{1}$ and HK $^{2}$ were responsible for the study concept and design. SAHK ${ }^{1}$, MSAM $^{1}$ and HK $^{2}$ contributed to data acquisition and analysis. SAHK ${ }^{1}$ drafted the manuscript. MSAM ${ }^{1}$ and $\mathbf{H K}^{2}$ provided critical revision of the manuscript for important intellectual content and approved final version for publication. All authors read and approved the final manuscript.

\section{Acknowledgement}

Not applicable

\section{References}

1. Lindquist S, Craig EA. The Heat-Shock Proteins. Annu Rev Genet. 1988 Dec;22(1):631-77. 
2. Saibil H. Chaperone machines for protein folding, unfolding and disaggregation. Vol. 14, Nature Reviews Molecular Cell Biology. Europe PMC Funders; 2013. p. 630-42.

3. Haase M, Fitze G. HSP90AB1: Helping the good and the bad. Vol. 575, Gene. Elsevier; 2016. p. 17186.

4. Sen CK, Khanna S, Roy S. Tocotrienols in health and disease: The other half of the natural vitamin $E$ family. Vol. 28, Molecular Aspects of Medicine. NIH Public Access; 2007. p. 692-728.

5. CHOMZYNSKI P. Single-Step Method of RNA Isolation by Acid Guanidinium Thiocyanate-PhenolChloroform Extraction. Anal Biochem. 1987 Apr;162(1):156-9.

6. Zhang Y, Zhang X, Shan P, Hunt CR, Pandita TK, Lee PJ. A Protective Hsp70-TLR4 Pathway in Lethal Oxidant Lung Injury. J Immunol. 2013 Aug 1;191(3):1393-403.

7. Voloboueva LA, Duan M, Ouyang Y, Emery JF, Stoy C, Giffard RG. Overexpression of mitochondrial Hsp70/Hsp75 protects astrocytes against ischemic injury in vitro. J Cereb Blood Flow Metab [Internet]. 2008 May 19 [cited 2020 Apr 3];28(5):1009-16. Available from: http://www.ncbi.nlm.nih.gov/pubmed/18091755

8. Mosser DD, Morimoto RI. Molecular chaperones and the stress of oncogenesis. Vol. 23, Oncogene. Nature Publishing Group; 2004. p. 2907-18.

9. Gosslau A, Ruoff P, Mohsenzadeh S, Hobohm U, Rensing L. Heat shock and oxidative stress-induced exposure of hydrophobic protein domains as common signal in the induction of hsp68. J Biol Chem. 2001 Jan 19;276(3):1814-21.

10. Yin JJ, Fu PP, Lutterodt H, Zhou YT, Antholine WE, Wamer W. Dual role of selected antioxidants found in dietary supplements: Crossover between anti- and pro-oxidant activities in the presence of copper. J Agric Food Chem. 2012 Mar 14;60(10):2554-61.

11. Vidrio $E$, Jung $H$, Anastasio $C$. Generation of hydroxyl radicals from dissolved transition metals in surrogate lung fluid solutions. Atmos Environ. 2008 Jun;42(18):4369-79.

12. Shchepinov MS. Reactive oxygen species, isotope effect, essential nutrients, and enhanced longevity. Rejuvenation Res [Internet]. 2007 Mar [cited 2020 Apr 3];10(1):47-59. Available from: http://www.ncbi.nlm.nih.gov/pubmed/17378752

13. Kim HJ, Hwang NR, Lee KJ. Heat shock responses for understanding diseases of protein denaturation. Vol. 23, Molecules and Cells. 2007. p. 123-31.

14. Kim N, Kim JY, Yenari MA. Pharmacological induction of the 70-kDa heat shock protein protects against brain injury. Neuroscience. 2015 Jan 2;284:912-9.

15. Dayalan Naidu S, Dinkova-Kostova AT. Regulation of the mammalian heat shock factor 1. FEBS J [Internet]. 2017 Jun 1 [cited 2020 Apr 3];284(11):1606-27. Available from: https://onlinelibrary.wiley.com/doi/abs/10.1111/febs.13999

16. Ahn SG, Thiele DJ. Redox regulation of mammalian heat shock factor 1 is essential for Hsp gene activation and protection from stress. Genes Dev. 2003 Feb 15;17(4):516-28. 
17. Moura CS, Lollo PCB, Morato PN, Amaya-Farfan J. Dietary nutrients and bioactive substances modulate heat shock protein (HSP) expression: A review. Vol. 10, Nutrients. MDPI AG; 2018.

18. Stetler RA, Gan Y, Zhang W, Liou AK, Gao Y, Cao G, et al. Heat shock proteins: Cellular and molecular mechanisms in the central nervous system. Vol. 92, Progress in Neurobiology. NIH Public Access; 2010. p. 184-211.

19. Khassaf M, McArdle A, Esanu C, Vasilaki A, McArdle F, Griffiths RD, et al. Effect of vitamin C supplements on antioxidant defence and stress proteins in human lymphocytes and skeletal muscle. J Physiol [Internet]. 2003 Jun 1 [cited 2020 Apr 3];549(2):645-52. Available from: http://www.ncbi.nlm.nih.gov/pubmed/12692182

20. Kim YS, Han JA, Cheong TB, Ryu JC, Kim JC. Protective effect of heat shock protein 70 against oxidative stresses in human corneal fibroblasts. J Korean Med Sci [Internet]. 2004 Aug [cited 2020 Apr 3];19(4):591-7. Available from: http://www.ncbi.nlm.nih.gov/pubmed/15308853

21. Creagh EM, Sheehan D, Cotter TG. Heat shock proteins - Modulators of apoptosis in tumour cells. Vol. 14, Leukemia. Nature Publishing Group; 2000. p. 1161-73.

22. Ran R, Lu A, Zhang, Tang Y, Zhu H, Xu H, et al. Hsp70 promotes TNF-mediated apoptosis by binding IKKY and impairing NF-KB survival signaling. Genes Dev. 2004 Jun 15;18(12):1466-81.

23. Wang K, Deng G, Chen G, Liu M, Yi Y, Yang T, et al. Heat shock protein 70 inhibits hydrogen peroxideinduced nucleolar fragmentation via suppressing cleavage and down-regulation of nucleolin. Cell Stress Chaperones [Internet]. 2012 Jan 30 [cited 2020 Apr 3];17(1):121-30. Available from: http://link.springer.com/10.1007/s12192-011-0292-4

24. Ikwegbue PC, Masamba P, Oyinloye BE, Kappo AP. Roles of heat shock proteins in apoptosis, oxidative stress, human inflammatory diseases, and cancer. Vol. 11, Pharmaceuticals. MDPI AG; 2018.

25. Niforou K, Cheimonidou C, Trougakos IP. Molecular chaperones and proteostasis regulation during redox imbalance. Vol. 2, Redox Biology. Elsevier B.V.; 2014. p. 323-32.

26. Penke B, Bogár F, Crul T, Sántha $M$, Tóth ME, Vígh L. Heat shock proteins and autophagy pathways in neuroprotection: From molecular bases to pharmacological interventions. Vol. 19, International Journal of Molecular Sciences. MDPI AG; 2018.

27. Walker CL, Pomatto LCD, Tripathi DN, Davies KJA. REDOX REGULATION OF HOMEOSTASIS AND PROTEOSTASIS IN PEROXISOMES. Physiol Rev [Internet]. 2018 [cited 2020 Apr 3];98:89-115. Available from: www.prv.org

28. Molecular Mechanisms behind Free Radical Scavengers Function against Oxidative Stress. - PubMed - NCBI [Internet]. [cited 2020 Apr 3]. Available from: https://www.ncbi.nlm.nih.gov/pubmed/28698499

29. Xu L, Voloboueva LA, Ouyang YB, Emery JF, Giffard RG. Overexpression of mitochondrial Hsp70/Hsp75 in rat brain protects mitochondria, reduces oxidative stress, and protects from focal ischemia. J Cereb Blood Flow Metab. 2009 Feb;29(2):365-74.

30. Selim ME, Rashed EHA, Aleisa NA, Daghestani MH. The protection role of heat shock protein 70 (HSP-70) in the testes of cadmium-exposed rats. Bioinformation. 2012 Jan 6;8(1):58-64. 
31. Topbas OF, Jehle R, Sinha P, Rüstow B. An electrophoretic study of vitamin E status and expression of heat shock proteins in alveolar type II and liver cells. Electrophoresis [Internet]. 2000 Nov [cited 2020 Apr 4];21(17):3552-7. Available from: http://www.ncbi.nlm.nih.gov/pubmed/11271470

32. Jackson MJ, Khassaf M, Vasilaki A, McArdle F, McArdle A. Vitamin E and the oxidative stress of exercise. In: Annals of the New York Academy of Sciences [Internet]. New York Academy of Sciences; 2004 [cited 2020 Apr 4]. p. 158-68. Available from: http://www.ncbi.nlm.nih.gov/pubmed/15753142

33. Fischer CP, Hiscock NJ, Basu S, Vessby B, Kallner A, Sjöberg LB, et al. Vitamin E isoform-specific inhibition of the exercise-induced heat shock protein 72 expression in humans. J Appl Physiol [Internet]. 2006 May [cited 2020 Apr 4];100(5):1679-87. Available from:

http://www.ncbi.nlm.nih.gov/pubmed/16384840

34. Niess AM, Fehrenbach E, Schlotz E, Sommer M, Angres C, Tschositsch K, et al. Effects of RRR-atocopherol on leukocyte expression of HSP72 in response to exhaustive treadmill exercise. Int $\mathrm{J}$ Sports Med [Internet]. 2002 Aug [cited 2020 Apr 4];23(6):445-52. Available from: http://www.ncbi.nlm.nih.gov/pubmed/12215965

35. Calabrese V, Scapagnini G, Catalano C, Bates TE, Geraci D, Pennisi G, et al. Regulation of heat shock protein synthesis in human skin fibroblasts in response to oxidative stress: role of vitamin $\mathrm{E}$. Int $\mathrm{J}$ Tissue React [Internet]. 2001 [cited 2020 Apr 4];23(4):127-35. Available from: http://www.ncbi.nlm.nih.gov/pubmed/11771776

36. Epstein SS, Forsyth J, Saporoschetz IB, Mantel N. An exploratory investigation on the inhibition of selected photosensitizers by agents of varying antioxidant activity. Radiat Res [Internet]. 1966 Jun [cited 2020 Apr 4];28(2):322-35. Available from: http://www.ncbi.nlm.nih.gov/pubmed/5941157

37. Da Costa LA, García-Bailo B, Badawi A, El-Sohemy A. Genetic determinants of dietary antioxidant status. Prog Mol Biol Transl Sci. 2012 Jan 1;108:179-200.

38. Flora SJS. Structural, chemical and biological aspects of antioxidants for strategies against metal and metalloid exposure. Vol. 2, Oxidative Medicine and Cellular Longevity. Hindawi Limited; 2009. p. 191-206.

39. Kamal MA, Raghunathan VA. Modulated phases of phospholipid bilayers induced by tocopherols. Biochim Biophys Acta - Biomembr. 2012 Nov 1;1818(11):2486-93.

40. Howard AC, McNeil AK, McNeil PL. Promotion of plasma membrane repair by vitamin e. Nat Commun. 2011 Dec 20;2(1):1-8.

41. Selvaraju TR, Khaza'ai H, Vidyadaran S, Mutalib MSA, Vasudevan R. The neuroprotective effects of tocotrienol rich fraction and alpha tocopherol against glutamate injury in astrocytes. Bosn $\mathrm{J}$ Basic Med Sci. 2014 Nov 1;14(4):195-204.

42. Durani LW, Hamezah HS, Ibrahim NF, Yanagisawa D, Nasaruddin ML, Mori M, et al. Tocotrienol-Rich Fraction of Palm Oil Improves Behavioral Impairments and Regulates Metabolic Pathways in AßPP/PS1 Mice. J Alzheimer's Dis. 2018;64(1):249-67.

43. Ramanathan N, Tan E, Loh LJ, Soh BS, Yap WN. Tocotrienol is a cardioprotective agent against ageing-associated cardiovascular disease and its associated morbidities. Vol. 15, Nutrition and 
Metabolism. BioMed Central Ltd.; 2018. p. 1-15.

44. Tocotrienol-Rich Fraction: A Gem In Palm Oil For Cardioprotection - Asia Pacific Food Industry [Internet]. [cited 2020 Apr 4]. Available from: https://apfoodonline.com/industry/tocotrienol-richfraction-gem-palm-oil-cardioprotection/

45. Wong SK, Kamisah Y, Mohamed N, Muhammad N, Masbah N, Fahami NAM, et al. Potential role of tocotrienols on non-communicable diseases: A review of current evidence. Vol. 12, Nutrients. MDPI $A G ; 2020$. p. 259.

46. Structural and dynamic membrane properties of alpha-tocopherol and alpha-tocotrienol: implication to the molecular mechanism of their antioxidant p... - PubMed - NCBI [Internet]. [cited 2020 Apr 4]. Available from: https://www.ncbi.nlm.nih.gov/pubmed/8399214

47. Mutalib MSA, Khaza'ai H, Wahle KWJ. Palm-tocotrienol rich fraction (TRF) is a more effective inhibitor of LDL oxidation and endothelial cell lipid peroxidation than a-tocopherol in vitro. Food Res Int. 2003 Jan 1;36(5):405-13.

48. Sen CK, Khanna S, Roy S. Tocotrienol: The natural vitamin E to defend the nervous system? In: Annals of the New York Academy of Sciences [Internet]. New York Academy of Sciences; 2004 [cited 2020 Apr 4]. p. 127-42. Available from: http://www.ncbi.nlm.nih.gov/pubmed/15753140

49. Packer L, Weber SU, Rimbach G. Molecular Aspects of $\{\{$ alpha\}\}-Tocotrienol Antioxidant Action and Cell Signalling. J Nutr [Internet]. 2001 Feb 1 [cited 2013 Dec 18];131(2):369S - 373. Available from: http://jn.nutrition.org/content/131/2/369S.short

50. Cytochrome P450 omega-hydroxylase pathway of tocopherol catabolism. Novel mechanism of regulation of vitamin E status. - PubMed - NCBI [Internet]. [cited 2020 Apr 4]. Available from: https://www.ncbi.nlm.nih.gov/pubmed/11997390

51. Sen CK, Khanna S, Roy S. Tocotrienols in health and disease: The other half of the natural vitamin $E$ family [Internet]. Vol. 28, Molecular Aspects of Medicine. 2007 [cited 2020 Apr 4]. p. 692-728. Available from: http://www.ncbi.nlm.nih.gov/pubmed/17507086

52. Characterization of the potent neuroprotective properties of the natural vitamin E alpha-tocotrienol. PubMed - NCBI [Internet]. [cited 2020 Apr 4]. Available from:

https://www.ncbi.nlm.nih.gov/pubmed/16923160

\section{Tables}

Table 1: Chang liver cell count using haemocytometer 
Test No. Total cells count in all squares Average cell count Density Total cell Number

\begin{tabular}{|c|c|c|c|c|}
\hline & & & cells/ml & (in $4 \mathrm{ml}$ ) \\
\hline 1 & 351 & 87.75 & $1.76 \otimes 10 \otimes$ & $7.02 \otimes 10 \otimes$ \\
\hline 2 & 547 & 136.75 & $2.74 \otimes 10 \bigotimes$ & $10.94 \otimes 10 \bigotimes$ \\
\hline
\end{tabular}

Dilution Factor $=2 ;$ Number of squares $=4$

Table 2: quantitation of the extracted tcRNA from Chang liver cells by the single step extraction method

\begin{tabular}{lllll} 
Sampel & $\begin{array}{l}\text { Absorbance } \\
(A 260)\end{array}$ & $\begin{array}{l}\text { Absorbance } \\
(\text { A280 })\end{array}$ & A260: A280 & $\begin{array}{l}\text { Concentration } \\
(\mu \mathrm{g} / \mathrm{ml})\end{array}$ \\
\hline C1c & 0.578 & 0.381 & 1.52 & 5785 \\
\hline C2d & 0.115 & 0.068 & 1.69 & 1145 \\
\hline L1 & 0.314 & 0.242 & 1.34 & 3500 \\
\hline L3 & 0.373 & 0.217 & 1.71 & 3750 \\
\hline T10c & 0.088 & 0.059 & 1.50 & 877 \\
\hline T20a & 0.207 & 0.183 & 1.13 & 2069 \\
\hline T30d & 0.956 & 0.870 & 1.10 & 9561 \\
\hline a10a & 1.77 & 1.63 & 1.53 & 17758 \\
\hline a20a & 0.06 & 0.037 & 1.63 & 597 \\
\hline a30d & 0.524 & 0.432 & 1.21 & 5234
\end{tabular}

$\mathrm{C} 1, \mathrm{C} 2$ = positive control samples; $\mathrm{L} 1, \mathrm{~L} 3$ = negative control samples; $\mathrm{T} 10, \mathrm{~T} 20, \mathrm{~T} 30=$ samples treated with 10, 20, $30 \mu \mathrm{g}$ TRF respectively; $\mathrm{a} 10, \mathrm{a} 20, \mathrm{a} 30=$ samples treated with 10, 20, $30 \mu \mathrm{g}$ tocopherol respectively; small letters $a, b, c, d=$ samples number $1,2,3,4$ of each category.

Table 3: level of significance of diffrence between control samples and treatment samples 


\begin{tabular}{|c|c|c|}
\hline \multirow[t]{2}{*}{ Sample } & \multicolumn{2}{|c|}{$\begin{array}{l}\text { Level of Significance of Difference } \\
\text { ( } p \text { value) }\end{array}$} \\
\hline & $\begin{array}{l}\text { CTRL+ } \\
(n=4)\end{array}$ & $\begin{array}{l}\text { CTRL- } \\
(n=4)\end{array}$ \\
\hline TRF $10(n=4)$ & 0.591 & $0.015^{\star}$ \\
\hline TRF $20(n=4)$ & $0.028^{*}$ & 0.051 \\
\hline TRF $30(n=4)$ & $0.032^{\star}$ & 0.224 \\
\hline a-Toc $10(n=4)$ & 0.814 & $0.006^{*}$ \\
\hline a-Toc $20(n=4)$ & 0.224 & $0.046^{*}$ \\
\hline a-Toc $30(n=4)$ & 0.052 & 0.326 \\
\hline
\end{tabular}

CTRL+ = positive control samples; CTRL- = negative control samples; TRF10, TRF20, TRF30 = samples treated with 10, 20, $30 \mu \mathrm{g}$ TRF respectively; $\mathrm{a}-$ Toc 10 , ; $\mathrm{a}-$ Toc 20 , ; $\mathrm{a}$ - Toc 30 = samples treated with 10, 20, $30 \mu \mathrm{g}$ tocopherol respectively.

Values followed by * superscript were significantly different * $p<0.05$

\section{Figures}




\section{HSP70 Expression \\ Mean \pm SEM}

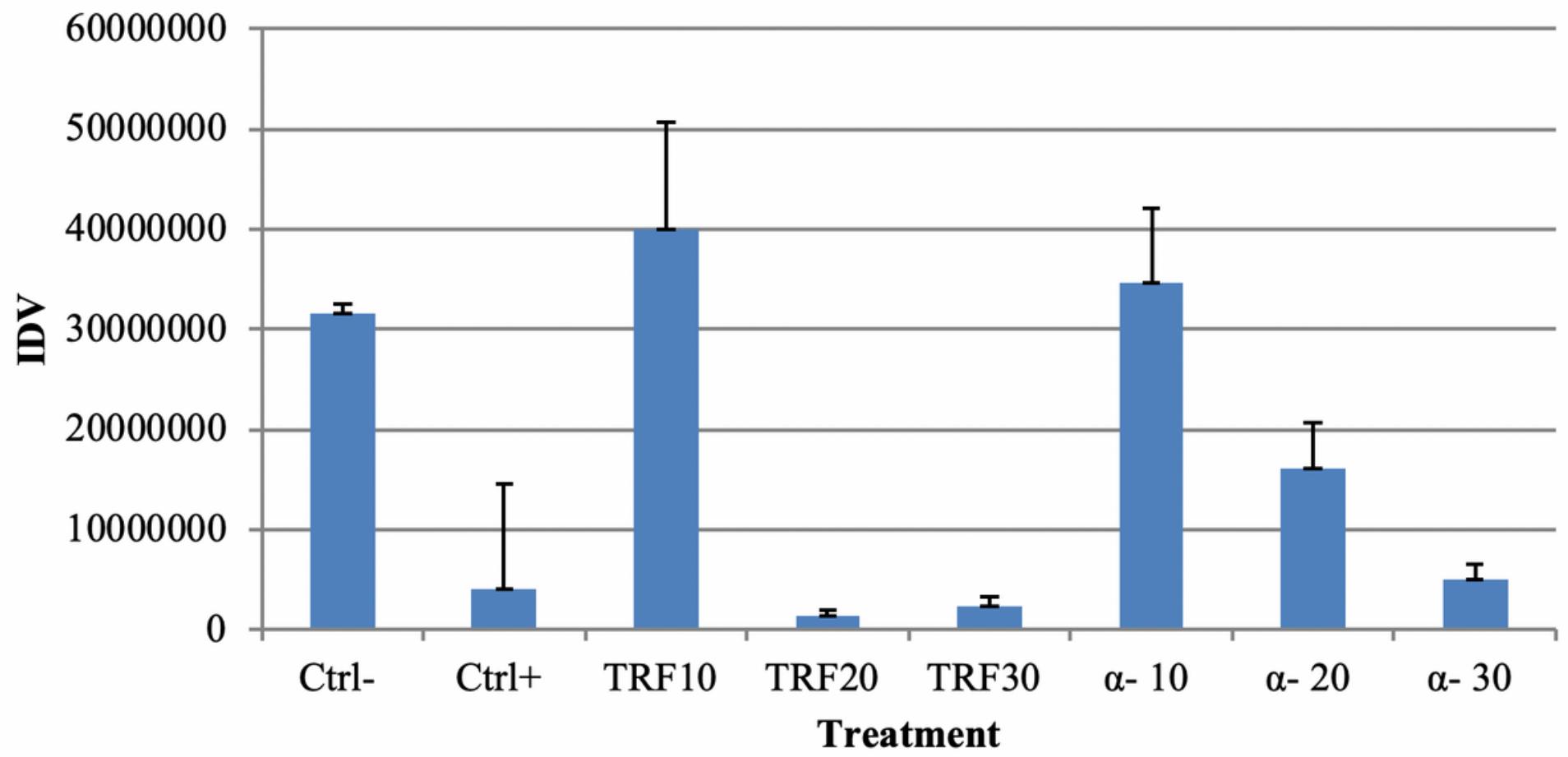

Figure 1

A graphical representation of the difference in the expression of HSP70. Ctrl+ : positive control samples Ctrl- : negative control samples TRF 10, 20, 30: samples treated with 10, 20, $30 \mu \mathrm{g}$ TRF respectively a-Toc 10, 20, 30: samples treated with 10, 20, $30 \mu \mathrm{g}$ Toc respectively Values expressed as Mean \pm SEM of the IDV of each sample $(p<0.05)$. 